\title{
The operation and capacity fade modelling of the lithium-ion cell for electric vehicles
}

\author{
Damian Burzyński ${ }^{1, *}$, and Leszek Kasprzyk ${ }^{1}$ \\ ${ }^{1}$ Poznan University of Technology, Institute of Electrical Engineering and Electronics, Poland
}

\begin{abstract}
The paper deals with the issues related to the operation and capacity fade modelling of lithium-ion cells. It includes the presentation of the electrochemical model of the cell in which the phenomenon of diffusion and transfer of charge on electrodes and in electrolyte was discussed. The circuit model of the cell designed for analysis of its behaviour in the conditions of the dynamically variable load was presented. The key aging processes which occur during the operation of the cells were characterised, and their impact on the wear of the cell was discussed. The model of the capacity fade of the lithium-nickelmanganese-cobalt cell was developed. The model parameters depends on the ambient temperature, the value of load current and the value of the average charge current. The results of the model were verified with the laboratory measurement.
\end{abstract}

\section{Introduction}

The rapid civilisational and technological developments observed nowadays has caused a greater and greater demand for electricity. According to many forecasts, it is likely that within the upcoming 20-30 years, the global electricity demand will almost double. This is one of the main reasons, for which the techniques and methods of analysis regarding electric energy storage are currently developed.

Analyses related to the behaviour of energy storage in buses and electric cars have been conducted in many research centres all over the world. Most frequently, they refer to the operation of electrochemical batteries and supercapacitors - often operating in the hybrid system [1-2]. The operation of these storages is contingent upon many chemical processes; therefore, different model types are used for the purpose of mapping of their operation. Depending on the expected accuracy, mathematical, circuit or non-deterministic models can be used.

In the case of electrochemical cells, the key issue of the modelling is the mapping of the wear of their capacity. The most frequently conducted studies refer to the impact of the respective factors which have a dominant impact on the capacity fade, such as ambient temperature, depth of discharge (DOD) and values of cyclic operation parameters (load/charge currents, cut-off charge voltage). Such an approach for the lithium-ionphosphate cell was presented in papers [3-4].

\footnotetext{
* Corresponding author: damian.burzynski@put.poznan.pl
} 


\section{Electrochemical model of the cell}

Electrochemical models enable detailed analysis of chemical processes leading to the cell polarisation. The processes which play a key role in the phenomenon of the cell polarisation are related to the transfer of charge and diffusion, and are divided into electrode processes and processes which occur in electrolyte [5-6]. The electrode processes - taking place on cell electrodes and in the area of double layers - they are related to the phenomena of transfer of load carriers, solvation, desolvation, adsorption or desorption of ions. On the other hand, the processes, which occur in the electrolyte solution, are responsible for the migration of ions from one electrode to the other.

The ion diffusion process on electrodes is determined by the Fick's law of diffusion [7-8]:

$$
\frac{\partial c_{s}}{\partial t}=\frac{D_{s}}{r^{2}} \frac{\partial}{\partial r}\left(r^{2} \frac{\partial c_{s}}{\partial r}\right)
$$

taking into consideration the following boundary conditions:

$$
\begin{gathered}
\left.\frac{\partial c_{s}}{\partial r}\right|_{r=0}=0 \\
\left.D_{s} \frac{\partial c_{s}}{\partial r}\right|_{r=R_{s}}=\frac{-j}{a_{s} F}
\end{gathered}
$$

where: $c_{s}-$ concentration of the solid phase $\left[\mathrm{mol} / \mathrm{cm}^{3}\right], D_{s}-$ solid phase diffusion coefficient $\left[\mathrm{cm}^{2} / \mathrm{s}\right], r-$ radial position of particle $[\mathrm{cm}], t-$ time $[\mathrm{s}], R_{s}-$ particle radius $[\mathrm{cm}], j-$ current density $\left[\mathrm{A} / \mathrm{cm}^{2}\right], a_{s}$ - interfacial surface area $\left[\mathrm{cm}^{2}\right], F-$ Faraday's constant $(96475 \mathrm{C} / \mathrm{mol})$.

Migration of ions in electrolyte is described by equation (4) [7-8]:

$$
\frac{\partial\left(c_{e} \varepsilon_{e}\right)}{\partial t}=\frac{\partial}{\partial x}\left(D_{e}^{e f f} \frac{\partial c_{e}}{\partial x}\right)+\frac{1-t_{+}^{0}}{F} j
$$

with the assumption of the lack of flow of current on terminals:

$$
\begin{aligned}
& \left.\frac{\partial c_{e}}{\partial x}\right|_{x=0}=0 \\
& \left.\frac{\partial c_{e}}{\partial x}\right|_{x=L}=0
\end{aligned}
$$

and with the assumption of the flow of ions through porous media: 


$$
D_{e}^{e f f}=D_{e} \varepsilon_{e}^{p}
$$

where: $c_{e}$ - concentration of the electrolyte phase $\left[\mathrm{mol} / \mathrm{cm}^{3}\right], \varepsilon_{e}-$ electrolyte phase volume fraction [-], $x$ - particle position [cm], $D_{e}^{e f f}-$ effective diffusion coefficient $\left[\mathrm{cm}^{2} / \mathrm{s}\right]$, $t_{+}{ }^{0}-$ ion transference number [-], $L-$ distance between electrodes [cm], $\varepsilon_{e}{ }^{p}-$ Bruggeman's porosity coefficient [-], $D_{e}-$ electrolyte diffusion coefficient $\left[\mathrm{cm}^{2} / \mathrm{s}\right]$.

Behaviour of the charge on electrodes is determined by the Ohm's law [7-8]:

$$
\frac{\partial}{\partial x}\left(\sigma^{e f f} \frac{\partial \phi_{s}}{\partial x}\right)-j=0
$$

with the maintenance of invariability of current density on cathode and anode terminals:

$$
-\left.\sigma_{-}^{e f f} \frac{\partial \phi_{s}}{\partial x}\right|_{x=0}=-\left.\sigma_{+}^{e f f} \frac{\partial \phi_{s}}{\partial x}\right|_{x=L}=\frac{I}{A}
$$

and also with the lack of flow through the separator:

$$
\left.\frac{\partial \phi_{s}}{\partial x}\right|_{x=\delta_{-}}=\left.\frac{\partial \phi_{s}}{\partial x}\right|_{x=\delta_{-}+\delta_{s e p}}=0
$$

where: $\sigma^{\text {eff }}$ - effective conductivity of the solid phase $[\mathrm{S} / \mathrm{cm}], \Phi_{s}-$ potential of the solid phase $[\mathrm{J} / \mathrm{mol}], \sigma^{\text {eff }}-$ effective conductivity of the anode $[\mathrm{S} / \mathrm{cm}], \sigma^{\text {eff }}+-$ effective conductivity of the cathode $[\mathrm{S} / \mathrm{cm}], I-$ load current $[\mathrm{A}], A$ - electrode plate area $\left[\mathrm{cm}^{2}\right]$, $\delta_{-}-$anode length $[\mathrm{cm}], \delta_{\text {sep }}-$ separator length $[\mathrm{cm}]$.

The process of charge transfer in the electrolyte solution is described by the following relationship (11) [7-8]:

$$
\frac{\partial}{\partial x}\left(\kappa^{e f f} \frac{\partial \phi_{e}}{\partial x}\right)+\frac{\partial}{\partial x}\left(\kappa_{D}^{e f f} \frac{\partial\left(\ln c_{e}\right)}{\partial x}\right)+j=0
$$

with the assumption of the boundary conditions (12) and (13):

$$
\begin{aligned}
& \left.\frac{\partial \phi_{e}}{\partial x}\right|_{x=0}=0 \\
& \left.\frac{\partial \phi_{e}}{\partial x}\right|_{x=L}=0
\end{aligned}
$$




$$
\kappa_{D}^{e f f}=\frac{2 R T \kappa^{e f f}}{F}\left(t_{+}^{0}-1\right)\left(1+\frac{d\left(\ln f_{ \pm}\right)}{d\left(\ln c_{e}\right)}\right)
$$

where: $\kappa^{e f f}-$ effective ionic conductivity $[\mathrm{S} / \mathrm{cm}], \Phi_{e}-$ potential of the electrolyte phase $[\mathrm{J} / \mathrm{mol}], \kappa^{e f f}{ }_{D}-$ effective diffusional conductivity $[\mathrm{S} / \mathrm{cm}], R-$ universal gas constant $(8,314 \mathrm{~J} / \mathrm{mol} \mathrm{K}), T$ - temperature $[\mathrm{K}], f_{ \pm}-$electrolyte activity coefficient [-].

Values of coefficients in formulas (1), (4), (7-9), (11) and (14) can be determined by means of advanced electrochemical methods such as, among others potentiometry, coulometry, voltammetry and impedance spectroscopy [5].

Potential of the electrolyte phase $\Phi_{e}$ and concentrations of solid phase $c_{s}$ and electrolyte phase $c_{e}$ which occur in equations (3-4), (8) and (11) depend on current density $j$, which can be determined based on the Butler-Volmer equation [5-8]:

$$
\begin{gathered}
j=j_{0}\left[\exp \left(\frac{\alpha_{+} F}{R T} \eta\right)-\exp \left(\frac{\alpha_{-} F}{R T} \eta\right)\right] \\
\eta=\phi_{s}-\phi_{e}-U
\end{gathered}
$$

where: $j_{0}-$ exchange current density $\left[\mathrm{A} / \mathrm{cm}^{2}\right], \alpha_{-}-$anode transfer coefficient $[-]$, $\alpha_{+}-$cathode transfer coefficient [-], $\eta-$ overpotential of cell [V], $U-$ equilibrium potential [V].

\section{Equivalent circuit model of the cell}

In circuit models (equivalent circuits), electrochemical processes which take place during the charge and discharge of the cell are modelled by means of standard RLC elements or CPE elements (constant phase elements) [9-14]. The selection of a specific structure of the equivalent circuit depends on the application of the model and, in certain cases, may significantly affect the accuracy of mapping of the cell operation. The model which enables the mapping of the phenomenon of polarisation and voltage drop on the internal resistance of the cell is presented in figure 1 .

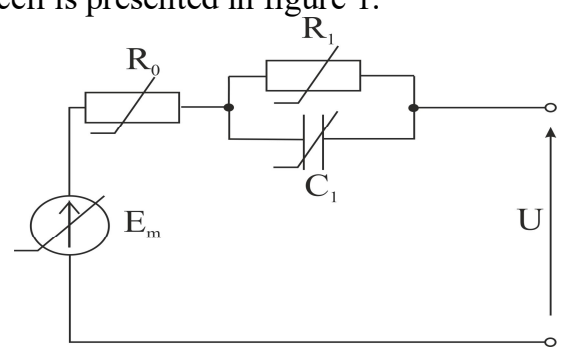

Fig. 1. Equivalent circuit of the electrochemical cell (first order model) [11]

In this model, all chemical processes which lead to the polarisation of the cell are modelled by means of a single mesh, which consists of ideal non-linear elements $R_{l} C_{l}$. Non-linear resistor $R_{0}$ maps the internal resistance of the cell, in which the electrolyte resistance has the largest share, while the non-linear source of direct current $E_{m}$ models the voltage on the unloaded cell terminals. 
In cases, where there is a necessity to take into account the chemical reactions which take place with different speeds - the equivalent circuit which contains several (at least two) meshes with different values of time constants must be applied. An example of such a model is shown in fig. 2 .

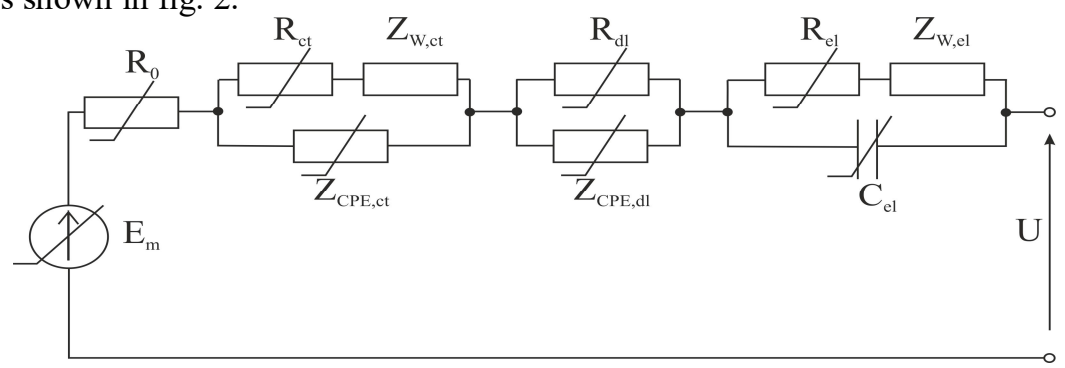

Fig. 2. Equivalent circuit of the electrochemical cell (complex model) [5]

The aforementioned model enables the mapping of the reactions of charge transfer and diffusion on electrodes, in the area of double layers and in electrolyte. The applied constant phase impedances $Z_{C P E, c t}$ and $Z_{C P E, d l}$ take into account the non-homogeneity of the structure of electrodes in the charge transfer processes, and the Warburg impedances $Z_{W, c t}$ and $Z_{W, e l}$ map the diffusion processes which occur in electrodes and in electrolyte solution respectively. The processes which take place in the double layer are most frequently modelled using non-linear capacitors or constant phase impedances.

The values of elements of equivalent circuits are identified most frequently by means of two methods - based on the cell voltage response to the rush of current [11], or by means of the electrochemical impedance spectroscopy (EIS) [5]. The first method may be applied successfully for equivalent circuits such as e.g. the circuit shown in figure 2 . In the case of the second order models and higher - as e.g. in fig. 3 - the EIS method must be used. For both estimation methods, it is necessary to take into account the fact that the determined values refer to the current cell state of charge (SOC), the current cell temperature and the current cell state of health $(\mathrm{SOH})$.

\section{Aging processes occurring in the lithium-ion cell}

Each process of the lithium-ion cell charge or discharge contributes to the permanent capacity fade of the cell. The capacity fade is a consequence of aging processes, which occur, in particular, on electrodes, in the area of their contact with electrolyte or in the electrolyte per se. According to many studies, the major aging process which affects the capacity fade is the phenomenon of formation of the passivation layer called solid electrolyte interface (SEI) on both electrodes of the cell [15-18]. The evolution of the aging processes which take place in double layers is presented in fig. 3. The SEI layer is a byproduct of many chemical reactions occurring between lithium ions, electrode material and electrolyte solution. (fig. 3-1). 


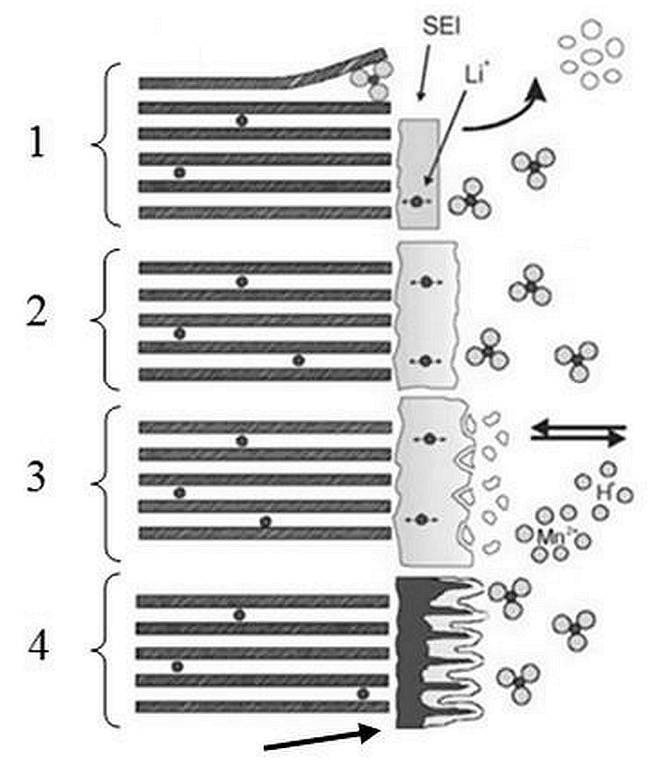

Fig. 3. Evolution of aging processes in double layer of lithium-ion cell [16]

Other equally important aging processes include the electrode galvanisation (fig. 3-4) and the phenomenon of formation of dendrites on the surface of the electrodes [17-18]. They are caused, above all by the charging of the cells at low temperatures, during discharge with high currents, and also during storage in the state of high or low charge. In extreme cases, the growth of dendrites may lead to the puncture of the separator and the electrodes short-circuit. The capacity fade of the cell is also a consequence of the mechanical degradation of the cell. In the case of electrodes, this is manifested by the reduction in their porosity, which results in the reduction in their areas capable of lithium ion intercalation. In view of the oxidisation phenomenon occurring on electrodes, the processes of their corrosion and dissolution in electrolyte must also be taken into account. A significant process is also the phenomenon of gassing and swelling of the cells, which takes place, among others, as a result of overcharge or operation at high ambient temperatures.

The aspect of the modelling of the capacity fade of lithium-ion cells is particularly difficult, because of the necessity to take into account the aging processes described above, which take place at the same time and are caused by several factors related to the exploitation of the cell. The process of modelling of the capacity fade may be divided depending on whether the cell is in the state of self-discharge or subjected to a load. In the first case, the state of charge and the cell storage temperature must be taken into account. In the second case, such factors as: ambient temperature, cell load parameters (depth of discharge and value of current) as well as the current state of health of the cell must be taken into account.

\section{Modelling of the capacity fade of the lithium-ion cell}

In order to develop the model of the capacity fade of the cell, the cylindrical lithiumion cell used to supply drivetrains of electric vehicles, with parameters listed in table 1, was selected. 
Table 1. Lithium-ion cell parameters used for the testing.

\begin{tabular}{|c|c|}
\hline Parameter & Value \\
\hline Type & $\mathrm{LiNi}_{0.33} \mathrm{Mn}_{0.33} \mathrm{Co}_{0.33} \mathrm{O}_{2}$ \\
\hline Nominal voltage & $3.63 \mathrm{~V}$ \\
\hline Rated capacity & $2600 \mathrm{mAh}$ \\
\hline Discharge cut-off voltage & $2.75 \mathrm{~V}$ \\
\hline Operating temperature & $\begin{array}{c}\text { Charge: } 0 \text { to } 45^{\circ} \mathrm{C} \\
\text { Discharge: }-20 \text { to } 60^{\circ} \mathrm{C}\end{array}$ \\
\hline
\end{tabular}

In order to develop the capacity fade model, 9 aging tests were performed, where the selected cell was subjected to cyclical operation. In order to maintain the constant ambient temperature during each test, the cells were placed inside the temperature chamber. The cyclic operation parameters were controlled by the equipment dedicated to electrochemical cells. In each conducted variant, the constant depth of discharge equal to $95 \%$ was maintained, and the values of final voltages for the charge and discharge amounted to $4.2 \mathrm{~V}$ and $2.75 \mathrm{~V}$ respectively. After each discharge, the cells were charged using the constant current-constant voltage (CC-CV) method. The pause between the charge and discharge procedures after each operating cycle was 15 seconds. Each of the performed tests ended when the cell lost $20 \%$ of its rated capacity - determined on the basis of the European standard - IEC 62660-1 - for cells used in electric vehicles. The parameters of the performed aging tests and the number of cycles performed are listed in table 2.

Table 2. Performed aging tests matrix.

\begin{tabular}{|c|c|c|c|c|}
\hline No. & $\begin{array}{c}\text { Ambient } \\
\text { temperature }\left[{ }^{\circ} \mathbf{C}\right]\end{array}$ & $\begin{array}{c}\text { Discharge } \\
\text { current }[\mathbf{A}]\end{array}$ & $\begin{array}{c}\text { Average } \\
\text { charge } \\
\text { current }[\mathbf{A}]\end{array}$ & $\begin{array}{c}\text { Number } \\
\text { of } \\
\text { cycles }\end{array}$ \\
\hline 1 & 15 & -5.20 & 2.20 & 312 \\
\hline 2 & 15 & -7.80 & 2.65 & 92 \\
\hline 3 & 15 & -2.60 & 2.08 & 466 \\
\hline 4 & 40 & -5.20 & 2.20 & 641 \\
\hline 5 & 40 & -7.80 & 2.65 & 274 \\
\hline 6 & 40 & -2.60 & 2.08 & 1085 \\
\hline 7 & 25 & -5.20 & 2.20 & 716 \\
\hline 8 & 25 & -7.80 & 2.65 & 251 \\
\hline 9 & 25 & -2.60 & 2.08 & 1250 \\
\hline
\end{tabular}

For the purpose of modelling of the capacity fade of the cell, the model of the twolayer feedforward artificial neural network, with the structure presented in fig. 4 was used.

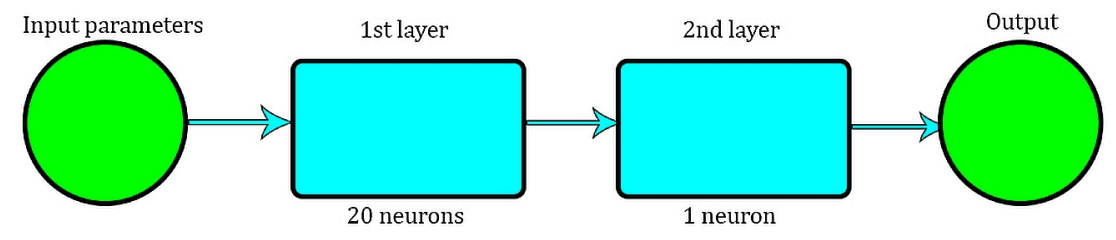

Fig. 4. Structure of the artificial neural network used to the test. 
The first layer of the network contained 20 neurons, and the second one contained 1 neuron. As the function of activation in the first layer, the normalized radial base function was assumed, while in the second layer - the linear function. The input network parameters were as follows: number of cycles, ambient temperature, value of average charge current and value of discharge current. The output parameter of the network was the useful capacity of the cell. The network teaching method involved the supervised teaching based on teaching data, which were the results of measurements of the useful capacity performed at the temperature of $15^{\circ} \mathrm{C}$ and $40^{\circ} \mathrm{C}$ (variants 1-6 from table 2). The teaching algorithm in the implemented network was the Levenberg-Marquardt algorithm with Bayesian regularisation. Before the teaching process, all the data were normalised and mixed. The verification of operation of the model was performed in two stages. During the first stage, the response of the model based on teaching data at the temperature of $15^{\circ} \mathrm{C}$ and $40^{\circ} \mathrm{C}$ was checked - the results and the mean relative error of the model were presented in fig. 5 .
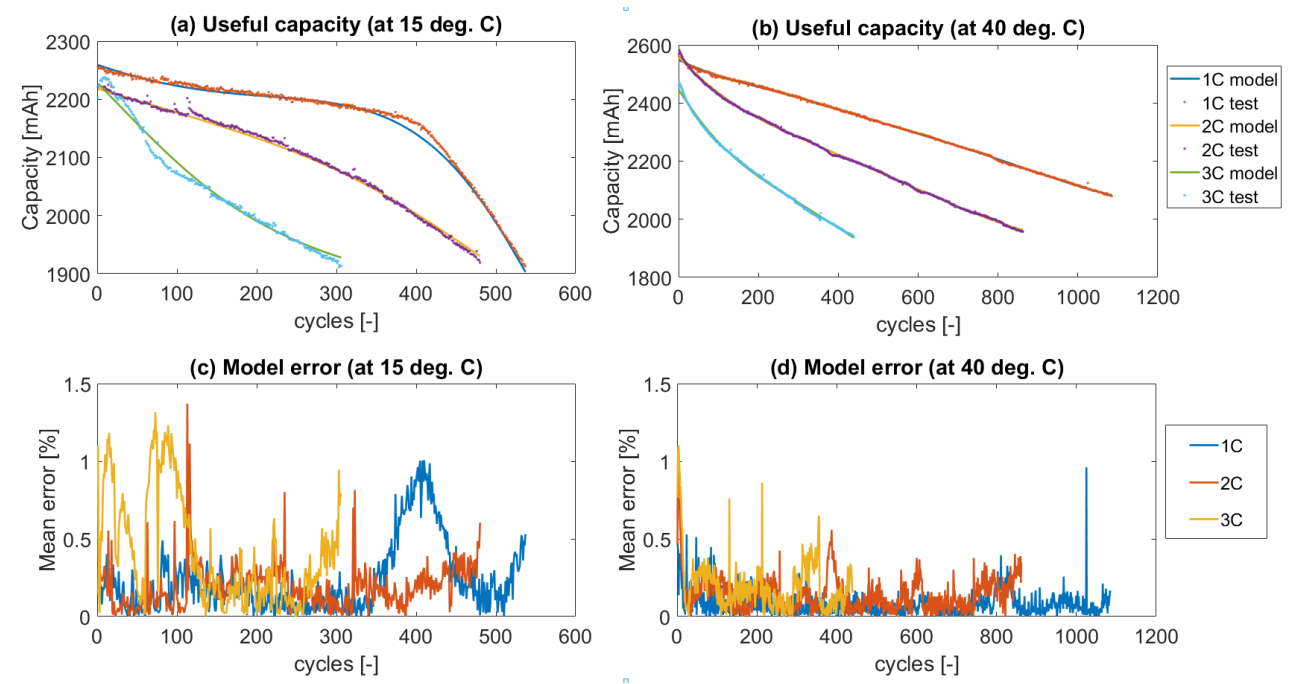

Fig. 5. Results of the artificial neural network training - capacity fade at $15^{\circ} \mathrm{C}$ (a) and $40^{\circ} \mathrm{C}(\mathrm{b})$, and model errors $15^{\circ} \mathrm{C}$ (c) and $40^{\circ} \mathrm{C}$ (d).

The second stage of verification of the functioning of the model was implemented at the rated ambient temperature - variants 7-9 from table 2, and then the results of the model were compared with experimental measurements. The results of the verification of the model at the rated temperature were presented in fig. 6 .

In the case of verification of the functioning of the model based on the teaching data (at the temperatures of $15^{\circ} \mathrm{C}$ and $40^{\circ} \mathrm{C}$ ) - for each variant, the mean relative error did not exceed $1 \%$. On the other hand, in the case of the verification at the rated temperature, the mean relative error for the discharge currents equal to $3 \mathrm{C}, 2 \mathrm{C}$ and $1 \mathrm{C}$ was $3.1 \%, 0.5 \%$ and $7.1 \%$ respectively. 
(a) Useful capacity (at 25 deg. C)

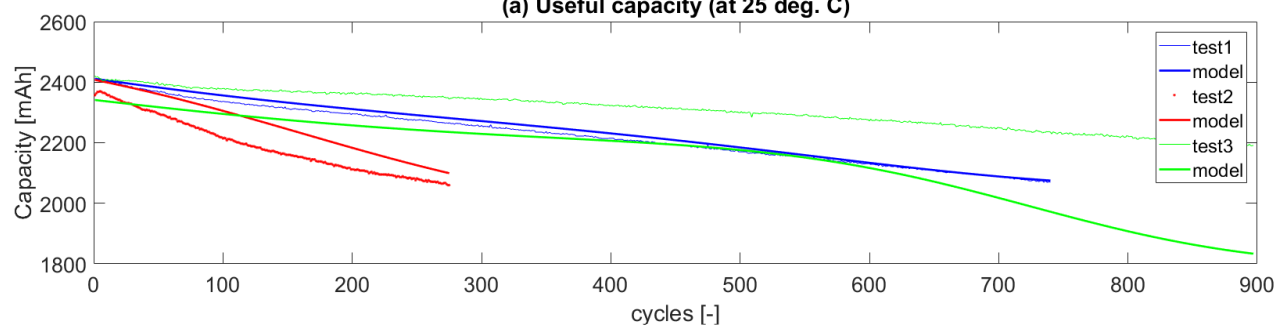

(b) Model error (at $25 \mathrm{deg}$. C)

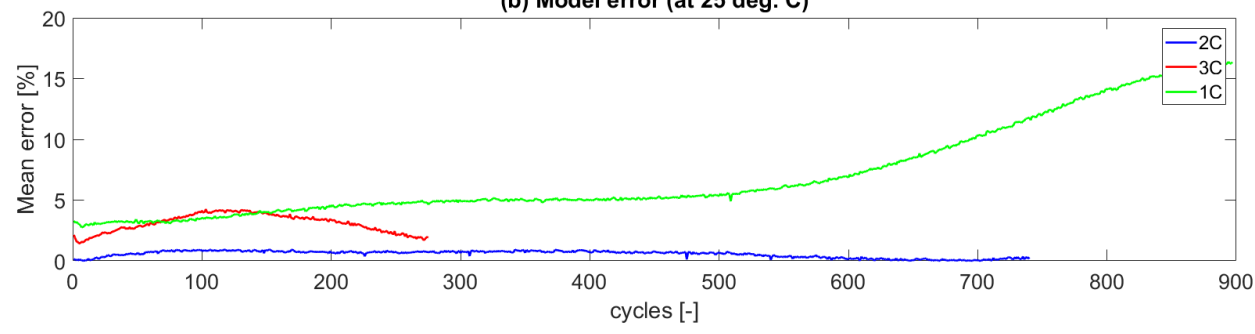

Fig. 6. Verification of capacity fade model in the rated temperature-capacity (a) and model error (b).

\section{Summary}

The paper deals with the subject of modelling of the operation and capacity fade of lithium-ion cells designed for electric vehicles. Because of a significant cost of the battery pack in electric vehicles, the knowledge regarding the expected cell capacity is currently of key significance. The electrochemical models enable detailed analysis of chemical processes which take place in the cell by means of the set of partial differential equations. These equations require the determination of many coefficients, which often require methods implemented only under laboratory conditions. The circuit models are characterised by lower accuracy in comparison to the electrochemical models, however, in many applications, the use of a single equivalent circuit (averaged for both electrodes) is sufficient and creates no difficulties in the implementation. The development of the capacity fade model for the lithium-ion cell requires the consideration of many factors which affect their degradation. The dominant factors include the ambient temperature, the depth of discharge, the final value of charge voltage and the values of charge and load currents of the cell, as well as the temperature and state of charge during the cell storage.

\section{References}

1. L. Kasprzyk, K. Bednarek, The selection of hybrid energy storage for electrical vehicle. Przegląd Elektrotechniczny 91, nr 12, 129-132, (2015)

2. M. Y. Ayad, M. Becherif, A. Aboubou, M. Wack, Electrical Vehicle Hybridized by Supercapacitors, IEEE International Energy Conference, pp. 79 -84, (2010)

3. N. Omar, M. A. Monem, Y. Firouz, J. Salminen, J. Smekens, O. Hegazy, H. Gaulous, G. Mulder, P. Van den Bossche, T. Coosemans, J. Van Mierlo, Lithium-iron phosphate based battery - Assessment of the aging parameters and development of cycle life model, Applied Energy 113, 1575-1585, (2014) 
4. J. Wang, P. Liu, J. Hicks-Garner, E. Sherman, S. Soukiazian, M. Verbrugge, H. Tataria, J. Musser, P. Finamore, Cycle-life model for graphite-LiFePO 4 cells, Journal of Power Sources 196, 3942 -3948, (2011)

5. A. J. Bard, L. R. Faulkner, Electrochemical methods: Fundamentals and Applications, Second Edition. John Wiley \& Sons, (2001)

6. H. J. Bergveld, Battery Management Systems - Design by Modelling. University Press Facilities, Eindhoven, pp. 55-67 (2001)

7. K. A. Smith, Ch. Rahn, Ch. Wang, Control oriented $1 D$ electrochemical model of lithium-ion battery, Energy Conversion and Management 48, 2565-2578 (2007)

8. E. Prada, D. Di Domenico, Y. Creff, J. Bernard, V. Sauvant-Moynot, A coupled OD electrochemical ageing \& electro-thermal Li-ion modeling approach for HEV/PHEV. IEEE Vehicle Power and Propulsion Conference, (2011)

9. A. Rahmoun, H. Biechl, Modelling of Li-ion batteries using equivalent circuit diagrams. Przegląd Elektrotechniczny 88, nr 7b, 152-156 (2012)

10. U. Westerhoff, K. Kurbach, F. Lienesch, M. Kurrat, Analysis of Lithium-Ion Battery Models Based on Electrochemical Impedance Spectroscopy. Energy Technology 4, 1620-1630, (2016)

11. M. Ceraolo, New dynamical models of lead-acid batteries. IEEE Transactions On Power Systems 15, No.4, (November 2000)

12. D. Burzynski, L. Kasprzyk, Modelling and simulation of lead-acid battery pack powering electric vehicle. E3S Web of Conferences 14, doi: 10.1051/e3sconf/20171401041 (2017)

13. L. Kasprzyk, Modelling and analysis of dynamic states of the lead-acid batteries in electric vehicles. Eksploatacja i Niezawodnosc - Maintenance and Reliability 19, nr 2, 229-236, http://dx.doi.org/10.17531/ein.2017.2.10 (2017)

14. L. Kasprzyk, K. Bednarek, D. Burzyński, Symulacja pracy akumulatorów kwasowoołowiowych. Przegląd Elektrotechniczny 12, pp. 61-64, (2016)

15. C. Hendricks, N. Williard, S. Mathew, M. Pecht, A failure modes, mechanisms, and effects analysis (FMMEA) of lithium-ion batteries, Journal of Power Sources 297, 113 120, (2015)

16. J. Vetter, P. Novak, M. R. Wagner, C. Veit, K.-C. Möller, J. O. Besenhard, M. Winter, M. Wohlfahrt-Mehrens, C. Vogler, A. Hammouche, Ageing mechanisms in lithium-ion batteries, Journal of Power Sources 147, 269-281, (2005)

17. Ch. R. Birkl, Matthew R. Roberts, E. McTurk, P. G. Bruce, D. A. Howey, Degradation diagnostics for lithium-ion cell, Journal of Power Sources 341, 373-386, (2017)

18. S. J. An, J. Li, C. Daniel, D. Mohanty, S. Nagpure, D. L. Wood III, The state of understanding of the lithium-ion-battery graphite solid electrolyte interphase (SEI) and its relationship to formation cycling, Carbon 105, 52-76, (2016) 